Cahiers $d u$ MONDE RUSSE

\section{Cahiers du monde russe}

Russie - Empire russe - Union soviétique et États indépendants

\section{$54 / 3-4 \mid 2013$}

L'expérience soviétique à son apogée - Culture et société des années Brežnev / Volume II

\title{
From the big screen to the streets of Kaunas
}

Youth cultural practices and Communist Party discourse in Soviet Lithuania

Du grand écran aux rues de Kaunas : les pratiques culturelles des jeunes et le discours du parti communiste en Lituanie soviétique

\section{Amanda Jeanne Swain}

\section{CpenEdition}

\section{Journals}

\section{Electronic version}

URL: https://journals.openedition.org/monderusse/7960

DOI: 10.4000/monderusse. 7960

ISSN: $1777-5388$

\section{Publisher}

Éditions de l'EHESS

\section{Printed version}

Date of publication: 1 July 2013

Number of pages: 467-490

ISBN: 9782713224393

ISSN: $1252-6576$

\section{Electronic reference}

Amanda Jeanne Swain, "From the big screen to the streets of Kaunas", Cahiers du monde russe [Online], 54/3-4 | 2013, Online since 01 July 2016, connection on 04 September 2022. URL: http:// journals.openedition.org/monderusse/7960 ; DOl: https://doi.org/10.4000/monderusse.7960 


\section{FROM THE BIG SCREEN TO THE STREETS OF KAUNAS}

\section{Youth cultural practices and Communist Party discourse in Soviet Lithuania*}

In mid-March 1972, the film Mažoji Išpažintis [Small Confession], based on the 1969 novel Arberonas by Vytautas Bubnys, was released in Soviet Lithuania. The film portrayed one week in the life of a secondary school student, Arūnas Gulbinas. "I am always waiting for Sunday," Arūnas said in the first line of the book. Sunday - a day off from school and work, when he can sleep in and take it easy - represented Arūnas' general attitude toward life. He started the day singing a pop-style song in English - "I love you; I love you; oh, oh, oh" - and dancing the twist. Indeed, the teenager spent much of his time during the week listening to music on a transistor radio and hanging out with his friends, not caring about the poor grades he received at school. In one scene, his best friend Benas played guitar and sang pop songs while sitting "American-style" (amerikoniškai) with his feet on the table. Arūnas was disrespectful towards his elders, talking back to both his father and the school director. Despite the entreaties of his class leader, Žifara, to behave appropriately, Arūnas ignored his responsibilities as a member of the Communist Youth Organization. Instead, he left silly verses signed "Arberonas" around the school. ${ }^{2}$ On Saturday, the end of the week and of the novel, Arūnas'

\footnotetext{
* The research for this article was made possible by a Fulbright-Hays Doctoral Dissertation Research Abroad Grant and by a Foreign Language and Area Studies fellowship, both with funds provided by the United States Department of Education. The views presented in this article are mine and do not represent the position of the United States Department of Education.

1. Vytautas Bubnys, Arberonas, Antras leidimas [Second edition], ed., (Vilnius: Vaga, 1972). Vytautas Bubnys (b. 1932) was a Soviet Lithuanian writer who published ten novels and worked for the journal Moksleivis [Pupil].

2. For example, "the voice that reaches the heavens comes from the biggest throat (i dangu balsas eina ne to, kuris turi didžiausią gerklę)" and "if a person is quiet, it does not mean that he has hooked a fish (jeigu žmogus tyli, dar nereiškia, kad jis žuvis ir užkibs ant kabliuko)."
} 
father was rushed to the hospital. As he waited to hear about his father's condition, Arūnas realized that he had been engaged in "childish games." Now the time had come to be an adult and take his life and responsibilities seriously.

Two months after the film Mažoji Išpažintis began showing at the Romuva Theater in Kaunas, the second largest city in Soviet Lithuania, two thousand young people in their teens and early twenties took to the streets for two days of mass demonstrations. The demonstrations followed the funeral of Romas Kalanta, a nineteen-year-old who had immolated himself on May 14 in the city center. ${ }^{3}$ As they marched through the streets on May 18, the young people shouted "freedom for Lithuania," "freedom for youth," and "freedom for hippies." After several hours, the crowd was broken up by riot police. When a crowd again gathered in the city center on the following day, the authorities called in army troops to suppress the street demonstrations. Publicly, the Soviet authorities presented a clearly defined narrative about the events in mid-May that portrayed Kalanta as mentally ill and cast the ensuing street demonstrations as the work of hooligans. In the only direct reference in the Soviet Lithuanian press, the May 20 issue of the Kaunas daily newspaper Kauno Tiesa gave a brief report on Kalanta's death and the "disturbance of public order" that followed his funeral. According to the newspaper, an official commission determined that Kalanta "committed suicide while in a morbid state." The article further stated that the demonstrations that followed Kalanta's death were a disturbance of the public order caused by "a small group of parasitical youth [who were] incited by irresponsible individuals."

In the aftermath of the May 1972 events, young people who participated in the street demonstrations and local Communist officials employed language of youthful immaturity similar to that used in the novel and the film to explain what had happened on the streets of Kaunas. Participants insisted in statements to the KGB that they had acted only out of "curiosity," thereby declaiming personal responsibility for their involvement in an unsanctioned mass demonstration. The authorities began with a narrative that focused on the corrupting influence of Western cultural practices and ended with an emphasis on the "immaturity" of Soviet youth who failed to recognize their own responsibilities in Communist society. Although

Each piece of paper ended with "what do you think? (Ką dabar galvoji?)" and was signed "Arberonas." "Arberonas" is a meaningless word formed in part by the two friends' names ARūnas and BEnas.

3. Along with his coat, Kalanta left on a bench a notebook in which he wrote "The system alone is responsible for my death (Dèl mano mirties kalta tik santvarka)." His family and friends said at the time - and again after Lithuania regained independence - that Kalanta did not discuss his plan to immolate himself nor had he indicated that he was suicidal. Kalanta was not actively involved in any "hippie" groups or dissident activities at the time of his death. Local Soviet authorities declared that he suffered from schizophrenia; although this diagnosis was rejected by an official psychiatric commissioned convened in 1989 .

4. "Kauno miesto prokuratūroje" [From the Kaunas City Prosecutor]. Kauno Tiesa [Kaunas Truth], May 20,1972,6. The psychiatric commission's report, as well as examples of Kalanta's "writings and drawings," are contained in files of the investigation of his self-immolation. "Baudžiamoji byla Nr. 20-2-036-72 dèl Romo Kalantos mirties fakto [Criminal Case Nr. 20-2-036-72 on the Fact of Romas Kalanta's Death]," May-June 1972. 
the novel and the film appear to present a stagnant discourse of what constituted proper Communist values and a condemnation of the influence of Western cultural practices on Soviet youth, the events on the streets in Kaunas revealed the fault lines of negotiations between authorities and youth over the acceptable boundaries of Soviet youth's cultural practices and social responsibilities in the late 1960s and early 1970s.

\section{Soviet Lithuania}

The collapse of the Russian empire in World War I provided the opportunity for some twenty leaders of the Lithuanian national movement to declare an independent Republic of Lithuania in 1918. A mere twenty years later, the onset of World War II led to the loss of Lithuanian independent statehood. Secret protocols to the 1939 Nazi-Soviet Non-Aggression Pact assigned Lithuania to the Soviet sphere of influence. In December 1939, Lithuania acceded to Soviet demands to station Red Army troops on Lithuanian territory. A Soviet ultimatum for the formation of a "pro-Soviet government" in Lithuania on June 14, 1940, led to the establishment of a "People's Government," which requested annexation by the Soviet Union, and to the deportation of approximately $10 \%$ of the Lithuanian population in 1941. The return of Soviet troops in January 1945 after four years of Nazi German occupation consolidated the initial incorporation of Lithuania into the Soviet Union. Thousands of Lithuanians retreated with the Germany army and ended up in displaced persons camps at the end of the war. They eventually immigrated to the United States, Canada, Australia or Western Europe. Although partisan bands took to the forests and attempted to resist militarily the Soviet occupation, they were not able to sustain control of Lithuanian territory and most laid down their arms under an amnesty granted after Stalin's death in 1953. By the 1960s, Lithuanians lived, were educated and worked within official Soviet social structures, with little evidence of active resistance to Soviet rule. ${ }^{5}$ Unlike its neighbors Latvia and Estonia, Lithuania did not experience an influx of Russian in-migration during the Soviet period. The republic's population remained at $80 \%$ ethnic Lithuanians, with Poles as the largest ethnic minority (12\%).

In many ways, Kaunas was a typical provincial Soviet city in 1972 and the young people who lived there were typical Soviet youth. The city saw a forty percent population increase from 219,300 in 1959 to 306,200 in $1970 .^{6}$ As a result of urbanization and the Soviet housing drive, young people in Kaunas grew up in apartment buildings and spent much of their leisure time socializing with

5. The 1970s saw the growth of resistance activities in Lithuania, including a broad-based Catholic dissident movement and numerous human rights dissidents. See, for example, Thomas Remeikis, Opposition to Soviet Rule in Lithuania, 1945-1980 (Chicago: Institute of Lithuania Studies Press, 1980) and V. Stanley Vardys, The Catholic Church, Dissent and Nationality in Soviet Lithuania (Boulder, CO: East European Quarterly; distributed by Columbia University Press, New York, 1978).

6. Romualdas Neimantas, Kaunas (Vilnius: Mintis Publishers, 1982), 34. 
other youth in the same housing block. The "courtyard culture" of young people in Kaunas meant that access to cultural artifacts and practices were shared across social and ethnic boundaries. Although it was a provincial Soviet city, Kaunas did have greater access to Western cultural products than other similar Soviet cities. Few foreigners traveled to Kaunas, but the number of residents with relatives living abroad was higher than many other Soviet cities. ${ }^{7}$ Kaunas had served as the interwar capital of Lithuania and the center of political and cultural life. As a result, a large percentage of its population had fled to the West with the return of the Soviet Army in 1944. By the 1960s, these émigrés were now sending packages of jeans, rock albums and magazines to their relatives who remained in Kaunas.

\section{Sources and methodology ${ }^{8}$}

Although the May 1972 events are regularly discussed in the post-1990 Lithuanian popular press, Kalanta's death and the ensuing street demonstrations have received limited attention by scholars of Lithuanian or Soviet history. The main scholarly work on Kaunas May 1972 was conducted for a conference at Vytautas Magnus University in 2002 at the thirtieth anniversary of the events. ${ }^{9}$ Scholars looked at various aspects of the May 1972 street demonstrations, including KGB accounts of the events, the LiCP's response, the response in the West and the relationship between cultural and ideological movements in the West and the events in Kaunas. That same year, a collection of essays and primary documents was published by two historians at Vytautas Magnus University. ${ }^{10}$ These works provide an important foundation for scholarship on the 1972 street demonstrations; however, they serve as preliminary assessments that were not later fully developed by these scholars (all of whom have pursued research agendas other than the 1972 events).

When they are mentioned in English-language works on the Soviet Union, the 1972 events in Kaunas are cited as examples of nationalist and/or anti-Soviet feeling

7. Kaunas was opened to one-day visitors in 1970. According to documents in the Kaunas City KGB Section files, 150 tourists from capitalist countries visited Kaunas in 1972. The document did not indicate when these visits took place (i.e., before or after the May events). Kaunas City KGB Section Files, Komitet gosudarstvennoi bezopasnosti pri Soviete Ministrov Litovskoi SSR. 1973. KGB Skyrius, Lietuvos Ypatingas Archyvas [KGB Division, Special Archives of Lithuania]. Vilnius. Fondas K-1, Ap. 1, By. 159. (Accessed Spring 2009).

8. In addition to archival sources discussed in this section, I conducted interviews in 2010 and 2011 with participants and observers of the 1972 street demonstrations. These interviews, conducted nearly forty years after the events were used primarily in this article to describe youth cultural practices at the time.

9. Articles from the conference were published as a special issue of Kauno Istorijos Metraštis [Kaunas History Yearbook] 4, (2003). Also, Arvydas Anušauskas, "KGB reakcija i 1972 ivykius [The KGB reaction to the 1972 events]," Genocidas ir Rezistencija, 13, 1 (2003): $80-83$, which was originally presented at the same conference as those published in the 2003 special issue of Kauno Istorijos Metraštis.

10. Egidijus Aleksandravičius and Salius Žukas, eds., Romo Kalantos auka: 1972 metu Kauno pavasaris [Romas Kalanta's Sacrifice: Kaunas Spring 1972] (Vilnius: Baltos Lankos, 2002). 
in the Lithuanian Soviet Socialist Republic (LiSSR), yet without an analysis of their origins or of their deeper political and social consequences. ${ }^{11}$ Vladimir Kozlov does not mention the events in Kaunas in his extensive work on popular protest in the Soviet Union. Yet the street demonstrations in Kaunas manifested a number of characteristics of mass popular protest he identified in other republics. Kozlov argues that popular protest was more frequent in the 1960s because Soviet citizens still believed that the promised bright future was possible; therefore, perceived abuses of power created a sense of violation among Soviet citizens. As a result, unrest on the part of a small group of people in an urban setting could quickly turn into a popular protest. As happened in Kaunas, bystanders at events in other Soviet republics either formed a "passively empathetic crowd" or were drawn into the protest. ${ }^{12}$ Kozlov points out that not all Soviet citizens had the capacity to engage in more sophisticated methods of communicating their discontent with Soviet abuses of power (such as letters to editors or complaint letters to specific agencies). Those who did not have such capacity, such as high school students or young workers, could be drawn into other forms of protest, for example, street demonstrations, that expressed an outcry against injustices..$^{13}$ Chants of "down with the police and their bananas" in the Kaunas street demonstrations certainly indicated that young people were responding to a perceived abuse of power by the police..$^{14}$

Although the young people on the streets in Kaunas in 1972 chanted "freedom for Lithuania," nationalist language was only one way of framing their discontent with the existing system. Indeed, reports of the demonstrations equally describe the chanting as focused on youth, with cries of "freedom for youth" and even "freedom for hippies." Kozlov argues that the reasons for protest and the language available to express discontent were not always aligned. He points out that popular protest in Soviet Central Asia against widespread violations of legality were often tinged with anti-Russian graffiti. ${ }^{15}$ In the same way, Saulius Grybkauskas demonstrates that worker-manager tensions in Soviet Lithuanian enterprises in the 1960s and 1970s were frequently framed in nationalist language even if the points of conflict were economic and employment-related. ${ }^{16}$

11. Examples include Ludmilla Alexeyeva, Soviet Dissent: Contemporary Movements for National, Religious, and Human Rights, trans., Carol Pearce and John Glad (Middletown, CT: Wesleyan University Press, 1985); Mark Beissinger, Nationalist Mobilization and the Collapse of the Soviet State (Cambridge: Cambridge University Press, 2002); Ben Fowkes, The Disintegration of the Soviet Union: A Study in the Rise and Triumph of Nationalism (New York: St. Martin's Press, 1997).

12. Vladimir A. Kozlov, Mass Uprisings in the USSR: Protest and Rebellion in the Post-Stalin Years, trans., Elaine McClarnand MacKinnon (London; Armonk, NY: M.E. Sharpe, 2002), 161.

13. Ibid.

14. "Bananas" was a slang term for rubber truncheons.

15. Kozlov, Mass Uprisings in the USSR, 306-307.

16. Saulius Grybkauskas, Sovietinè nomenklatūra ir pramoné Lietuvoje 1965-1985 metais [The Soviet Nomenklatura and Industry in Lithuania 1965-1985] (Vilnius: Lietuvos Istorijos Instituto Leidykla, 2011). 
An analysis of KGB interrogation statements of young people who participated in the street demonstrations reveals the political practices through which young people defined their relationship to post-Stalinist Soviet authority and society. Of the four hundred and two people arrested on May 18, the KGB investigation files contain interview statements (liudytojo apklausos protokolas) from fifty-two individuals who participated to some extent in the street demonstrations..$^{17} \mathrm{KGB}$ interview statements are, of course, problematic sources. While investigative reports state the total number arrested, there are no full lists of arrested individuals in the investigation files. There is no indication why these fifty-two statements are the only ones extant or of what kind of duress might have been applied to the young people who were questioned. Despite these concerns, a careful analysis of the statements can still provide certain types of information about the young people who participated and how they talked to authorities about the nature of the street demonstrations and their participation in them. Of the fifty-two people whose interview statements are in the files, forty were teen agers, while twelve were twenty years old or older. ${ }^{18}$ Seventeen of the young people were members of the Communist Youth Organization, while one was a candidate member of the Communist Party. ${ }^{19}$ The remaining thirty-four were identified as "nepartinis [not affiliated with the Communist Party]." Sixteen were female; thirty-six were male. All of those questioned were residents of Kaunas. The statements demonstrate that young Lithuanians born and raised in post-Stalinist Soviet Union had learned to "speak Bolshevik," using contemporary Soviet ideological language for their own purposes. ${ }^{20}$

Communist Party reports and transcripts of speeches at Party activist meetings in the immediate aftermath of the street demonstrations establish that local Communist Party officials were searching for an ideologically acceptable narrative

17. "Baudžiamoji byla 09-2-013-72 [Criminal Case 09-2-013-72]", May-July 1972. The statements rarely indicate what questions were asked, although it is possible to infer certain questions based on common elements contained in the statements. The statements were primarily handwritten, presumably by a KGB official or stenographer because the handwriting for many of the statements is the same. Each statement is signed at the end by the person from whom it was taken. Several of the individuals were interviewed two or three times with a statement from each interview.

18. The three oldest participants for which there are interrogation statements were 24, 27, and 28. The interrogation statements represent a younger demographic than the statistics provided by the KGB for the total 402 people who were arrested. For the extant interrogation statements, over one-third were under 18 and nearly half were age $18-21$. KGB reports stated that, of those arrested for participation in the street demonstrations, $25 \%$ were under age $18,17 \%$ were age $18-21$, and $28 \%$ were $21-25$.

19. At one-third, the percentage of Communist Youth Organization members in the extant interrogation statements was higher than the one-quarter with party affiliation of the 402 people arrested.

20. For work on "speaking Bolshevik" during the Stalinist period, see Stephen Kotkin, Magnetic Mountain: Stalinism as a Civilization (Berkeley - Lost Angeles: University of California Press, 1995) and Jochen Hellbeck, Revolution on My Mind: Writing a Diary Under Stalin (Cambridge, MA: Harvard University Press, 2006). For young people's capacity to use Soviet forms of speaking in late socialism, see Alexei Yurchak, Everything Was Forever, Until It Was No More: The Last Soviet Generation (Princeton, NJ: Princeton University Press, 2006). 
of the events. Like KGB documents, LiCP documents are also problematic. It is not clear to what extent speeches given to the Party faithful and reports sent up the chain of command as far as Moscow accurately represent Lithuanian Communist authorities' opinions about the causes of the May 1972 street demonstrations. Again, despite these concerns, a close reading of the documents reveals the ways in which the local authorities chose from among a repertoire of ideological language to explain what had happened on the streets of Kaunas.

\section{"Really existing socialism"}

"Really existing socialism" was a key ideological constraint within which the Communist Party of Lithuania (LiCP) had to work as it crafted a narrative of the events of May 18-19. As a result, the Communist Party rejected nationalist, class and generational conflicts as the cause of participation by two thousand young people in mass demonstrations in Kaunas. In a speech on June 2, Antanas Guiga, First Secretary of the Kaunas district Party organization, denied that the demonstrations had a nationalist character, "inasmuch as the majority of participants were young men of Lithuanian nationality, but there were also Russians, Jews, and others." ${ }^{21}$ Communist officials had reason to be concerned that events in the LiSSR would be labeled "nationalist." Soviet-wide economic and political reforms had created tension between center and periphery that tapped into existing concerns in Moscow about nationalist tendencies in the Baltic Soviet Socialist Republics and resulted in greater exercise of control by the central leadership. The Lithuanian leadership had been subjected to accusations that "nationalist elements" attempted to "preach localism," "mislead individual officials into discrimination on the basis of nationality in the cadres policy," and "supplant the criticism of the cult of the individual by criticism of Leninism." Attacks on Lithuanian "bourgeois nationalism" appeared both in Pravda and Voprosi Filosofii [Questions of Philosophy]. ${ }^{22}$

In the view of the Communist Party officials, the street demonstrations following Kalanta's self-immolation were instead representative of a broader "youth problem" in the Soviet Union. A May $30 \mathrm{LiCP}$ document put the events of May 18-19 in the context of other incidents in which youth "behaved in a disorderly and undisciplined manner at music concerts, basketball games, boxing matches and other events." ${ }^{23}$

21. Of the fifty-two individuals for whom interrogation statements are available in the files, only three have identifiably Russian names. The statistical summary provided by the KGB does not include ethnicity.

22. Teresa Rakowska-Harmstone, "The Dilemma of Nationalism in the Soviet Union," in John W. Strong, ed., The Soviet Union under Brezhnev and Kosygin: The Transition Years (New York: Van Nostrand Reihold Company, 1971), 122.

23. "Postanovlenie biuro tsentral'nogo komiteta KPLitvi ob usilenii politicheskoi i organizatorskoi raboti $v$ sviazi s antiobshchestvennimi proiavleniiami v g. Kaunase [Decree concerning the need to strengthen political and administrative work in connection with the anti-social developments in the city of Kaunas]," The Central Committee of the Communist Party of Lithuania. May 30, 1972. LKP Skyrius, Lietuvos Ypatingas Archyvas [Communist Party of Lithuania Division, Special 
In a June 2 speech, Lithuanian Komsomol Secretary Poškus emphasized that "the majority of the city's young people has been, is now, and will continue to be faithful to their class duties in their daily work and affairs, proving their allegiance to the work of the Communist Party." He gave as an example the participation of young people from Soviet Lithuania in the march "Through the places of Revolutionary, Labor and Military Glory of the Communist Party and the Soviet People," which was praised by General Secretary Leonid Brezhnev at the Communist Party of the Soviet Union's $24^{\text {th }}$ Party Congress. However, he decried the recent number of "anti-social attacks" carried out by students of general education and professional technical schools, and in certain cases, by university students and working young people. ${ }^{24}$

At the same time, Communist officials clearly distinguished youth problems in contemporary Soviet society from those in Western capitalist societies. Guiga emphasized that the events of May 18-19

in no way bear a class character... Among those who participated in the violation of public order were young workers, students, the children of workers and service people, and even of kolkhoz workers, because most of the students from professional and technical schools come from rural areas. ${ }^{25}$

Guiga also stated that

Although some degree of disagreement is to be expected between children and their parents, and between younger people and older people, there exists no disagreement whatsoever about the fundamental issues of life and politics, and there is no such thing as a generation gap in our society.

These assurances, however, seemed to contradict Communist officials' explicitly articulated concerns about Soviet Lithuanian youth in the early 1970s.

Concerns about a growing youth problem were intertwined with Soviet concerns with so-called hooliganism. Since the 1950s, "hooliganism" had been constructed in the media as the primary social problem among youth. The flexible category of petty hooliganism introduced under Khrushchev made it easier for Soviet authorities to prosecute and intimidate Soviet citizens. ${ }^{26}$ From 1960 on,

Archives of Lithuania], Vilnius. Fondas 1771, Ap. 247, By. 79. (Accessed 2009). Although the speech does not identify specific details, incidents that fit this list have been reported in other sources. For example, disturbances followed a boxing match between Lithuanian and Uzbek teams in July 1960. Romuald J. Misiunas and Rein Taagepera, The Baltic States: Years of Dependence, 1940-1990, 2nd ed. (Berkeley: University of California Press, 1993).

24. "Protokol No. 3."

25. "Protokol No. 3 sobraniia gorodskogo partiinogo aktiva [Meeting of the city Party activists]," Communist Party of Lithuania. June 2, 1972. LKP Skyrius, Lietuvos Ypatingas Archyvas [Communist Party of Lithuania Division, Special Archives of Lithuania], Vilnius. Fondas 3110, Ap. 61, By. 15. (Accessed 2009).

26. Brian Lapierre, "Making Hooligans on a Mass Scale," Cahiers du Monde russe, 47, 1-2 (2006): 373. 
the criminal code defined hooliganism as "intentional actions that rudely violate public order and express clear disrespect for society." ${ }^{27}$ Campaigns against hooliganism saturated Soviet society in the 1960s and the number of people prosecuted for hooliganism rose steeply. The campaign against hooliganism was part and parcel of the post-Stalinist transition from social control through violence to social control through discipline. By attempting to exercise control of everyday behaviors such as public socializing and interactions between fellow citizens, the state further blurred the line between personal and private. The Soviet authorities' goal in prosecuting hooliganism was to create a society that reflected the ideals of "really-existing socialism," a society in which Soviet people acted in civilized ways that benefited the collective.

The Communist Youth Organization (Komsomol in Russian; Komjaunimas in Lithuanian) served as the key force to exert Soviet control over young people, especially those like the fictional Arūnas Gulbinas who engaged in Western cultural practices. In his speech to the $24^{\text {th }}$ Party Congress, Brezhnev emphasized that

The Komsomol's central task has been and remains to bring up young people in the spirit of Communist ideals and devotion to our Soviet motherland, in the spirit of internationalism, and actively to propagate the norms and cultural values of our society. ${ }^{28}$

As the Komsomol increasingly assumed responsibility for the ideological training of young people it became more and more a mass organization of social control. ${ }^{29}$ Indeed, membership in official groups, including the Communist Youth Organization, continued to provide the most reliable access to recreation, higher education and jobs - and young Lithuanians participated in Komsomol and other official activities or groups throughout the 1960s and early 1970s. The total membership of the Lithuanian Communist Youth Organization more than doubled from 1960 to 1965 , growing from 131,012 to 226,311 . It continued to increase, rising to 281,853 in 1971 (a $46 \%$ increase from 1960)..$^{30}$ Over the same period, the total LiSSR population increased by $15 \%$, from $2,711,000$ in 1959 to

27. Ibid., 349, Footnote 1. "There were two types of criminal hooliganism differentiated according to seriousness and punishment: simple hooliganism (prostoe khuliganstvo), for which punishments ranged from fines to one year in prison, and malicious hooliganism (zlostnoe khuliganstvo), for which prison sentences ranged from three to five years."

28. Report of the CPSU Central Committee to the 24th Congress of the Communist Party of the Soviet Union, Delivered by Leonid Brezhnev, General Secretary of the CPSU Central Committee, March 30, 1971, 93-94.

29. Hilary Pilkington, “'The Future Is Ours': Youth Culture in Russia, 1953 to the Present," in Catriona Kelly, David Shepherd, eds., Russian Cultural Studies: An Introduction (Oxford: Oxford University Press, 1998), 370-371.

30. Lietuvos Komjaunimas skaičiais 1919-1979 statistikos duomenu rinkinys (Vilnius: Mintis, 1980), 68, 70. There was, however, a sharp drop off in the total number of new Komjaunimas members in Lithuania from $1965(43,346)$ to $1966(32,235)$. The annual new membership numbers then increased significantly over the next five years, reaching 42,496 in 1971. 
$3,128,000$ in $1970 .{ }^{31}$ Kaunas, in particular, saw steadily increasing numbers of new Komsomol members, from 34,838 in 1965 to 41,350 in $1971 .{ }^{32}$ The $19 \%$ increase in Komsomol membership, however, was outpaced by the $40 \%$ population growth in Kaunas over the same time period. ${ }^{33}$

\section{Kaunas as a site of Soviet youth cultural practices}

Like urban youth across the Soviet Union in the late 1960s and early 1970s, young people in Kaunas engaged in youth cultural practices that pushed the boundaries of acceptable leisure activities. ${ }^{34}$ Access to images of the West through film and television, music of the West through short-wave radio broadcasts, and material goods from the West brought in by tourists and received by mail from relatives living abroad meant that youth lifestyles and cultural practices in Soviet cities came to resemble more closely those of their counterparts in the West. The adoption and adaptation of Western cultural practices in Soviet Lithuania was influenced by a number of factors. Firstly, access to information was circumscribed. Films and other visual artifacts were not necessarily direct portrayals of Western lifestyles or leisure activities. Young people saw photographs of hippies and youth in the West primarily through Soviet anti-Western propaganda, which often presented extreme portrayals of dress and cultural practices. Looks and practices drawn from foreign films might already be outdated in the West. For example, the 1960 American film The Apartment was not shown in Kaunas until a decade later when clothing styles in the United States had already changed. Soviet youth had to recreate Western clothing styles using materials at hand.

Among all the influences of Western culture, rock music was at the core of what many young people saw as a modern lifestyle. Young people in Soviet Lithuania listened to rock music primarily on BBC and Radio Luxembourg. ${ }^{35}$ They eagerly awaited the latest song by The Doors, Jimi Hendrix, Creedence Clearwater

31. T. Shabad, "The 1979 Census and Some Demographic Trends in the Soviet Union," GeoJournal 4, 1 (1980): 85.

32. Lietuvos Komjaunimas skaičiais 1919-1979 statistikos duomenų rinkinys, 98.

33. Romualdas Neimantas, Kaunas (Vilnius: Mintis Publishers, 1982), 34.

34. A number of scholars have documented the flourishing of youth culture and particularly the influence of Western cultural practices on Soviet youth. See, for example, John Bushnell, Moscow Graffiti: Language and Subculture (Boston: Unwin Hyman, 1990); Pilkington, “The Future Is Ours'..."; Donald J. Raleigh, Soviet Baby Boomers: An Oral History of Russia's Cold War Generation (Oxford: Oxford University Press, 2012); William J. Risch, "Soviet "Flower Children'. Hippies and the Youth Counter-Culture in 1970s L'viv," Journal of Contemporary History, 40, 3 (2005); Alexei Yurchak, Everything Was Forever, until It Was No More: The Last Soviet Generation (Princeton, Oxford: Princeton University Press, 2006); Sergei I. Zhuk, Rock and Roll in the Rocket City: The West, Identity, and Ideology in Soviet Dniepropetrovsk, 1960-1985 (Baltimore, MD: Johns Hopkins University Press, 2010).

35. Voice of America was considered the "jazz station" by Lithuanians whom I interviewed in 2010 . 
Revival, and the Animals. ${ }^{36}$ The Polish rock band Czerwone Gitary [Red Guitars] was also popular. Listening to rock music did indeed become a pursuit that drew young people out of the orbit of official recreational activities for youth. Young people in Kaunas would gather in homes and listen to rock music on the radio, on home-made recordings or on albums sent by relatives living abroad. ${ }^{37}$ Young people also made rock music. Teenagers, primarily young men, copied the music they heard on the radio or on albums from the West. Informal jam sessions in homes led to the formation of amateur bands. Ričardas Kolaitis, who formed the band Decima with several classmates, explained that they would listen to Radio Luxemborg and practice playing their favorite songs. ${ }^{38}$ Because they did not speak English, they did not understand the lyrics. Over time, the band began to write their own lyrics in Lithuanian to the melodies that they learned from the radio ${ }^{39}$ Decima played together from 1968 to 1972 . The band played at local youth functions in Kaunas, although they never received formal recognition.

Faced with the influx of rock music from the West, Soviet authorities allowed "vocal-instrumental ensembles" (VIAs) in an attempt to produce ideologically acceptable music that would appeal to young people. These bands were expected to play a strict Soviet repertoire and while "they could be youthful, electrified, even shaggy-haired," Soviet authorities were quite clear that VIAs were not "rock bands." Musicians in VIAs received professional status and were paid for performing, unlike the many amateur bands that flourished at the time. No matter how they were officially described, young people viewed the amateur bands and VIAs involved in the Kaunas music scene in the late 1960s and early 1970s as rock bands. ${ }^{41}$ Aitvarai [Kites] (1967-1976) was formed by students in the Kaunas Polytechnic Institute's Construction Department. The group first performed in the 1967 KPI student festival. They toured outside of Lithuania to Latvia, Poland, Ukraine, Armenia and East Germany in the early 1970s. The band Gelès [Flowers] (1970-1972) coincidentally played its final concert on May 14, 1972, in the town of Kèdainai. Gintarèliai [Amber People] (1966-1973) began as a Beatles cover

36. Although much has been written about the influence of the Beatles in the Soviet Union, they did not rank high in my interviewees' lists of favorite bands. The Beatles craze entered the Soviet Union in the early 1960s. See, for example, Leslie Woodhead, "How the Beatles Rocked the Kremlin," (UK: 2009).

37. Ričardas Gužas (Kaunas, Lithuania; April 20, 2011). Interview with author; Ričardas Kolaitis (Kaunas; June 1, 2011). Interview with author; Hana Šumilaitè (Kaunas; July 7, 2011). Interview with author.

38. Kolaitis (Kaunas; June 1, 2011). Interview with author.

39. This was a common practice by amateur bands in Soviet Lithuania. However, because these songs were rarely recorded and forty years has passed, most of the lyrics are lost.

40. Kristin Roth-Ey, Moscow Prime Time: How the Soviet Union Built a Media Empire That Lost the Cultural Cold War (Ithaca - London: Cornell University Press, 2011), 165.

41. These bands were mentioned in interviews and also appear in YouTube videos of Soviet Lithuanian "rock music." Details about the individual bands comes from the encyclopedia Mindaugas Peleckis, ed. Lietuvos Rokas: ištakos ir raida [Lithuanian Rock: Origins and Evolution] (Vilnius: Mintis, 2011). 
band and later represented the Soviet Union abroad, playing concerts in Finland, the UK and the Congo. The band Kertukai [The Tough Guys] (1966-1971) was the only local Kaunas band to receive official designation as a VIA. The hippie group "The Company" even generated its own rock band, Raganiai [Sorcerers] (1969-1972). A number of amateur rock bands in Kaunas attained semi-formal status through the Kaunas Polytechnic Institute. ${ }^{42}$ In 1967, students in KPI's Automotive Department formed an informal "big beat" fan club that met in a student's apartment. The students registered the club as a KPI student group in 1969. Each week the group would gather at the institute to listen to records and record music on a magnetifon reel-to-reel tape recorder. ${ }^{43}$ The "big beat" club organized the first rock concert in Kaunas - called a "pop session" - in the spring of 1971. KPI's student-run pop club continued to organize concerts and dances in the early 1970s. ${ }^{44}$

\section{Kids on the streets: young people explain their actions}

These multi-faceted and thriving youth cultural practices provided the context in which young people responded to Kalanta's suicide by gathering at his family's home and the site of his self-immolation on the afternoon of his funeral. Their demands for "freedom for youth" and "freedom for hippies," along with "down with the police and their bananas," indicated a desire to push further the boundaries of acceptable Soviet youth cultural practices. An analysis of KGB interrogation statements of young people who participated in the street demonstrations reveals that these young people saw themselves as participating primarily in an event that manifested a common identity as youth. ${ }^{45}$

42. According to The Great Soviet Encyclopedia $3^{\text {rd }}$ edition, "In 1972 the Kaunas Polytechnic Institute included departments of automation, engineering economics, light industry, machine building, mechanics, radio electronics, electrical engineering, chemical technology, construction and sanitation engineering, as well as evening, correspondence and preparatory divisions [...] In the 1972-73 academic year the institute had 15, 000 students, with 1,000 instructors [...]" Bol'shaia Sovetskaia entsiklopediia [Great Soviet Encyclopedia] $3^{\text {rd }}$ ed. (M., 1969-1978), s.v. "Kaunas Polytechnic Institute." (www.rubricon.com, accessed online January 2013).

43. Interview with Antanas Stancevičius, Algimintas Piligrimas, and Algimintas Šešelgis, pop club members in Enrika Striogaitė and Rimantė Tamoliūmienè, eds., Laisvès proveržiai sovietiniame Kaune nuo slapto pogrindžio iki atviro protesto [Breakthrough of freedom in Soviet Lithuania from secret underground to open protest] (Kaunas: Kauno Apskrities Viešoji Biblioteka, 2007), 97-101.

44. Edmundas Janušaitis (Kaunas; February 2, 2011). Interview with author; Kolaitis (Kaunas; June 1, 2011). Interview with author; Aurelijus Varnas (Kaunas; February 7, 2011). Interview with author.

45. All interrogation statements cited by first name and last initial in the following footnotes are taken from the investigation files in Baudžiamoji Byla 09-2-013-72 [Criminal Case 09-2-013-72], Kauno Miesto VK VRV (Vidaus Reikalū Vadybos) Tardymo Skyrius [Investigation section of Kaunas Internal Affairs Department] Lietuvos TSR Prokuratūra (Ypatingai Svarbių Bylų Tardytojas) [LiSSR Prosecutor.] May-July 1972. KGB Skyrius, Lietuvos Ypatingas Archyvas [KGB Division, Special Archives of Lithuania], Vilnius. Fondas K-1, Ap. 58a, By. 47644/3 (five volumes). (Accessed January 2009). 
References to actions that could be deemed "nationalist" did appear in descriptions of the street demonstrations, but were downplayed by participants. One young woman said that "Lietuva [Lithuania]" was spelled out with flowers at the place where Kalanta had immolated himself. ${ }^{46}$ Several people stated that the crowd sang Lithuanian national songs, although they also reported that the crowd did not know the words and the singing died out. ${ }^{47}$ Some observers attributed nationalist motivations to the crowd. A twenty-two year old worker described a balding man, approximately forty years old, who "had great joy that there are still young Lithuanian patriots." ${ }^{48}$ Despite these examples, the majority of those interviewed did not emphasize nationalist motivations on the part of the crowd. They reported that the crowd shouted "freedom for hippies" and "freedom for youth" as frequently as "freedom for Lithuania."

While some participants reported political aspects to the protest, these were similarly deemphasized in the statements taken by KGB interrogators. According to several of the interrogation statements, members of the crowd shouted "we don't like Soviet authority; we will fight for freedom" and "we will fight for freedom and independence." ${ }^{49}$ None of the young people who were questioned, however, claimed political motivations for themselves or for the majority of participants. A young man stated, "While watching the others, not the hippies, I understood that they approved of the shouted slogans only sort of as joking. I didn't see political content in those shouts." ${ }^{50}$ As evident from this quote, many of the participants associated the street demonstrations with the hippies, even though they themselves were not hippies. Most of those questioned who were at the Kalanta home identified a "young man with long hair" as the instigator of the march to the city center. When questioned about the main actors during the impromptu memorial service and the march to the police headquarters, others also identified young men with long hair or unnamed hippies as the instigators. The young people who were questioned attributed to the hippies a desire for social and personal freedom, not solely political freedom. An eleventh grade student explained, "I understood the shouts to mean that hippies felt freedom, which is similar to anarchy, was a necessity." 51 An eighteen year old worker noted "I understood 'hippie' as youth with long hair or behaving freely (behaving how they want)." 52

Even given an incentive to downplay nationalist or political intentions, descriptions of the street demonstrations as a youth event still took center stage in the interrogation statements. A tenth grade student described that "there were girls

46. Birutė Š., "Baudžiamoji byla 09-2-013-72 [Criminal Case 09-2-013-72]."

47. Birutė Š. and Vytautas P., "Baudžiamoji byla 09-2-013-72 [Criminal Case 09-2-013-72]."

48. Albertas K.,"Baudžiamoji byla 09-2-013-72 [Criminal Case 09-2-013-72]."

49. Viktoras Š., "Baudžiamoji byla 09-2-013-72 [Criminal Case 09-2-013-72]."

50. Rimas G., "Baudžiamoji byla 09-2-013-72 [Criminal Case 09-2-013-72]."

51. Ibid.

52. Kęstutis P., "Baudžiamoji byla 09-2-013-72 [Criminal Case 09-2-013-72]." 
and guys more or less my age [...] I understood that a youth demonstration was occurring. ${ }^{, 53}$ Several of the participants reported that members of the crowd called for a recognition of youth. A eleventh grade student said that individuals laying flowers in the park called on youth to gather every May 14 and declared that this date would be Lithuanian youth's liberty day. ${ }^{54}$ Another student said that that the crowd shouted "Let this place unite as a symbol of youth." 55 Although they did not explicitly refer to previous altercations between the police and young people, many of those questioned noted that the crowd shouted "down with the police and their bananas," providing an indication that there had been previous run-ins between young people and the police..$^{56}$

Despite evidence of thriving youth cultural practices in Kaunas that pushed the boundaries of acceptable Soviet activities, the young people detained after the street demonstrations were - perhaps not surprisingly - unwilling to push boundaries in their interrogation statements. The participants denied that they had done anything wrong by simply being present on the street, even when identifying the events as a protest against the Soviet system. In doing so, they used language that downplayed responsibility for their actions and mimicked the characterization of young people as "childish" found in the novel Arberonas and the film Mažoji Išpažintis.

Nearly all of the young people explained to the authorities that they themselves only participated in the demonstrations out of curiosity. Young people with no personal connection to Kalanta were drawn to his funeral out of curiosity about the young man who had committed suicide so dramatically. One young woman explained that she was not employed or in school so she had free time and was curious to see the funeral. Once at the Kalanta home, she went with the crowd to the city park because she wanted to see what would happen. ${ }^{57}$ A seventeen year old worker said simply that the funeral of a young man was interesting to her so she decided to attend. ${ }^{58}$ Both Kalanta's self-immolation and the date and time of the funeral were common knowledge in Kaunas by Thursday, May 18. A tenth grade pupil said, "I knew from people talking that Kalanta's funeral would occur on May 18 at 16:00 and I decided to attend his funeral. I wanted to see what would

53. Ričardas T., "buvo merginos ir vaikinai maždaug mano amžiaus [...] supratau kad vyksta jaunimo demonstracija." "Baudžiamoji byla 09-2-013-72 [Criminal Case 09-2-013-72]."

54. Eugenijus Ž., "taip pat sakè, kad reikia jaunimui susrinkti kiekvienais metais gègužès $14 \mathrm{~d}$. prie susideginimo vietos ir, kad ta diena bus Lietuvos jaunimo laisvès diena." "Baudžiamoji byla 09-2-013-72 [Criminal Case 09-2-013-72]."

55. Ričardas T., "tegul ta vieta būria jaunimo simboliu." "Baudžiamoji byla 09-2-013-72 [Criminal Case 09-2-013-72]."

56. LiCP documents refer to incidents in which young people "behaved in a disorderly and undisciplined manner at music concerts, basketball games, boxing matches and other events." Such interactions in the context of leisure activities reveal a potentially broad-based youth discontent in Soviet Lithuania. "Postanovleniie."

57. Janina J., "Baudžiamoji byla 09-2-013-72 [Criminal Case 09-2-013-72]."

58. Nadiedža M. Despite this young woman's Russian first and last names, her interrogation statement was taken in Lithuanian. "Baudžiamoji byla 09-2-013-72 [Criminal Case 09-2-013-72]". 
happen so I also went to the city park." ${ }^{59}$ Only a few participants said that they knew Kalanta personally. A young man, who was a member of the Communist Party, said that he decided to go to the funeral because he was acquainted with Kalanta. ${ }^{60}$ A student at the polytechnic school explained that he was in the same class with Kalanta from second through eleventh grade, therefore, he decided to attend his funeral. Even those young people who said they attended the funeral because they knew Kalanta gave curiosity rather than personal connection as the reason for participating in the street demonstrations. When the crowd began to march to the city center, the polytechnic school student said "I went out of curiosity to see what else would happen." ${ }^{61}$

Based on the extant interrogation statements, the age of the participants was the primary attraction for young people who joined the crowd. A technical school student stated that "on that day, when I saw a large crowd of noisy youths, it personally interested me." ${ }^{62}$ Similarly, an eleventh grade student said that "he went along with the kids." ${ }^{63}$ A tenth grade student explained "I stood near the circle of shouting youths and I also shouted 'long live the long-haired ones [hippies]'. ." ${ }^{64}$ A number of young people also remarked that joining with other young people was a liberating experience. As a worker declared, "It wasn't important to me what the shouts meant; I was caught up in the spirit of the other shouters. It was interesting and cheerful. [I wanted] to be with the others [...] to behave uninhibitedly and freely." ${ }^{65}$

The size of the crowd, which the young people repeatedly referred to as "huge" (didžiulis), drew many of the young people who had not gone to the Kalanta home but rather joined the crowd after seeing it on the street. Indeed, the crowd that gathered on Thursday, May 18, was the largest unofficial public gathering the young people would have seen or even heard about in Soviet Lithuania. In some cases, they noticed a crowd gathered outside the Kalanta home. One young man said that he saw a lot of people gathered at the Kalanta house after leaving work about 3:30 in the afternoon and he went out of curiosity to see what was going on. ${ }^{66}$ In other cases, they noticed a crowd in the city center. Another, on his way home from work about 6:00 p.m. stated that he was surprised to see a lot of people gathered in the city park and went to see what was happening ${ }^{67}$ An eleventh grade student explained that he went past the city park on his way home from school because

59. Liuda A. This young woman has a Russia first name and Lithuanian last name. Her interrogation statement was taken in Lithuanian. "Baudžiamoji byla 09-2-013-72 [Criminal Case 09-2-013-72]."

60. Vytautas K., "Baudžiamoji byla 09-2-013-72 [Criminal Case 09-2-013-72]."

61. Viktoras M., "Baudžiamoji byla 09-2-013-72 [Criminal Case 09-2-013-72]."

62. Vladas K., "Baudžiamoji byla 09-2-013-72 [Criminal Case 09-2-013-72]."

63. Euginijus Ž., "Baudžiamoji byla 09-2-013-72 [Criminal Case 09-2-013-72]."

64. Virginija S., "Baudžiamoji byla 09-2-013-72 [Criminal Case 09-2-013-72]."

65. Nadiedža M., "Baudžiamoji byla 09-2-013-72 [Criminal Case 09-2-013-72]."

66. Remigijus K., "Baudžiamoji byla 09-2-013-72 [Criminal Case 09-2-013-72]."

67. Rimantas U.,"Baudžiamoji byla 09-2-013-72 [Criminal Case 09-2-013-72]." 
his house was nearby. He saw many young people placing flowers in the place where the self-immolation had occurred so he went to see what was happening. ${ }^{68}$ A student at a technical school stated that he was out walking around the city at about 4:30 p.m. When he walked past the Musical Theater, he saw a lot of people gathered and went to take a look. ${ }^{69}$ Similarly, a young worker said that he was on his way to visit a friend at about 4:00 p.m. He saw a crowd of people walking and shouting on Laisvès Aleja and he went along with the crowd. ${ }^{70}$ A student at a technical school saw a large crowd on Laisvès Aleja after leaving work and joined in as they marched to the police headquarters. ${ }^{71}$

In their explanations to the authorities, the young people claimed they were not doing anything wrong when they joined the crowd. Some argued that they weren't actively participating, simply watching the event. A tenth grade pupil summed up the sentiments expressed by a number of those questioned, "Neither I nor my friend [...] joined a disturbance against public order. We didn't do anything bad and only looked at what happened." 72 Others acknowledged that they participated in the march and shouted slogans, but still denied that their actions were unacceptable. A young woman pointed out that she did not think that she was engaged in anything "bad [blogas]" when she joined the crowd in its march from the Kalanta home to the city center. ${ }^{73}$ Another student at a technical school also noted that he joined in the noise-making without thinking that he did "something bad." " Since these statements appear in interrogation statements, it is difficult to determine if they express genuine opinions or are solely an attempt to downplay participation in an event that was clearly not acceptable to the authorities.

Given the nearly unanimous use of "curiosity" as an explanation for participation, it is apparent that the young people believed that it was an acceptable explanation of their actions to give to authorities. As an eighth grade pupil stated "I have to note that I participated in the procession on May 18 only from curiosity and that I had no other aims." 75 Certainly, young people who were acquainted with Kalanta would have had an incentive to downplay their personal connection with a young man who had publicly committed suicide and been declared mentally ill. Curiosity also served to downplay political or nationalist motivations that might be unacceptable to authorities. At the same time, "curiosity" reflects broader Soviet discourses about youth that equated behavior perceived as inappropriate with "immaturity."

68. Rimas G.,"Baudžiamoji byla 09-2-013-72 [Criminal Case 09-2-013-72]."

69. Rimantas J., "Baudžiamoji byla 09-2-013-72 [Criminal Case 09-2-013-72]."

70. Vytautas P., "Baudžiamoji byla 09-2-013-72 [Criminal Case 09-2-013-72]."

71. Algimintas S., "Baudžiamoji byla 09-2-013-72 [Criminal Case 09-2-013-72]."

72. Liuda A., "Baudžiamoji byla 09-2-013-72 [Criminal Case 09-2-013-72]."

73. Audra K. This young woman has a Lithuanian first name and a Russian last name. Her interrogation statement is in Lithuanian. "Baudžiamoji byla 09-2-013-72 [Criminal Case 09-2-013-72]."

74. Vladas K., "Baudžiamoji byla 09-2-013-72 [Criminal Case 09-2-013-72]."

75. Ričardas D., "Baudžiamoji byla 09-2-013-72 [Criminal Case 09-2-013-72]." 


\section{The LiCP: searching for an ideologically acceptable narrative}

Internal LiCP reports and speeches produced during the four weeks after Kalanta's self-immolation and the ensuing street demonstrations provide evidence that Communist Party officials similarly defined the events of May 18-19 as youth-driven. In response to information from the KGB on the demographics of the young people who participated in the demonstrations, Communist party officials constructed a narrative that posited "politically immature young people" spurred to "anti-social actions" in the form of rioting by "anti-Soviet and nationalist elements," in particular the "so-called hippies." The tropes of "immature" youth corrupted by Western influences that appear in the novel Arberonas and the film Mažoji Išpažintis appear in the LiCP's narrative of the events of May 18-19. This characterization of young people as unthinkingly manipulated by outside forces rejected an interpretation of the events as a manifestation of real discontent.

A close analysis of LiCP documents reveals that Party officials' interpretation of the nature of the street demonstrations, the character of the participants, and the cause of their participation transitioned from blaming "marginal elements" in society to attributing the unrest to "politically immature" young people. A series of documents produced in the weeks after the street demonstrations - a May 20 report on the measures taken by the Party in response to the events, a May report to the LiCP Central Committee summarizing the events, a May 30 Decree outlining measures to be taken in light of the events, speeches from a June 2 meeting of Party activists, and a June 14 speech by First Secretary Antanas Sniečkus to Party activists - demonstrate how the Communist Party's interpretation of the events changed over time. The documents refer to "nationalist," "anti-Soviet" and "foreign bourgeois elements" taking advantage of the events, yet they do not designate these as the primary causes. While this narrative appears clear cut on the surface, it is fraught with ambiguity. Each interpretation in the documents - hooligans, hippies, and politically immature youth - had particular consequences for the political and social environment in Kaunas and for the Communist Party as the ideological vanguard. Initially, Communist officials had to explain what brought young people out into the streets in response to Kalanta's self-immolation. In doing so, they shied away from labeling the young people who participated in the street demonstrations as "nationalist" or "anti-Soviet." Once the narrative based on politically immature youth had been constructed, they had to explain the causes of political immaturity among young people in Kaunas. The LiCP construction of the events of May 18-19 downplayed explanations that might imply agency on the part of the young people who participated in the demonstrations. Instead the LiCP emphasized its own failure to inculcate young people with the proper attitudes and values, a response grounded in the Soviet practice of "self-criticism."

In the first report after the street demonstrations, Party officials blamed hooligans for "disturbing the social order." The May 20 report characterized the street demonstrations as "disorders" (besporiadki) and emphasized that participants included hippies, "a certain proportion of young non-cadre workers, a number 
of people with prior convictions and people who are not engaged in any kind of socially useful work." 76 Given the saturation of the concept of "hooliganism" in the Soviet Union, it is not surprising that participants in the street demonstrations in Kaunas were immediately labeled as "hooligans." After all, two thousand young people in the streets refused to disperse when ordered to do so and the crowd had to be broken up by police.

Confronted with statistics of those arrested for participating in the demonstrations, Communist officials could no longer write off the events as the actions of hooligans. The composition of the people who were arrested certainly differed from the characteristics put forth in the May 20 report. Only 5\% of those arrested were unemployed. Nearly half were workers and more than one-third were students. Even more compelling, nearly one-fourth were members of Communist Youth League. ${ }^{77}$ Once the KGB investigation revealed the demographics of the participants in the street demonstrations, the language of hooliganism in LiCP documents faded and nearly disappeared. In its description of the crowd that formed in the center on May 18 , the summary report makes reference to "certain criminal elements in the crowd" that engaged in vandalism, but these "petty criminals" played a small role given the scale of the unrest. In the June report and speeches, the term "hooligans" was only used when describing public responses to the events and not in descriptions of the young people on the street. For example, the June 2 report included the term "hooligan" once in a statement that "the absolute majority of the population [...] condemns the hooligans." Similarly, speeches by the Communist Party leadership in June speeches commended the public for "correctly interpreting" the unrest as the work of "hooligans." 78

Instead the LiCP focused on a second marginalized group - "hippies." A summary report prepared by the LiCP accused "so-called hippies" for instigating the events and for corrupting young people. The report repeated a KGB allegation

76. "Informatsiia o priniatikh merakh i provedennikh meropriiatiiakh Kaunasskim Gorkom I Gorraikomami Kp Litvi v sviazi s proisshestviiami v gorode Kaunase 14-19 Maia 1972 g. [Information about measures and actions taken by the Kaunas municipal committee and the city district committees of the Communist Party of Lithuania in connection with the events in the city of Kaunas on 14-19 May 1972]," The Central Committee of the Communist Party of Lithuania. May 20, 1972. LKP Skyrius, Lietuvos Ypatingas Archyvas [Communist Party of Lithuania Division, Special Archives of Lithuania], Vilnius. Fondas 3110, Ap. 61, By. 34. (Accessed 2009). In Kozlov's analysis of mass protest in the Soviet Union, the term "besporiadki" is translated "disorders" or "disturbances." I have adopted the same translation. Vladimir A. Kozlov, Mass Uprisings in the USSR.

77. "Spravka ob antiobshchestvennikh i natsionalisticheskikh proiavlenniiakh $\mathrm{v}$ respublike imevshikh mesto posle 14 maia 1972 goda [Memorandum on anti-social and nationalist manifestations that took place in the Republic after May 14, 1972]," Komitet gosudarstvennoi bezopasnosti pri sovete ministrov Litovskoi SSR [LiSSR KGB]. June? 1972. Fondas K-1 Ap. 3, By. 793, 154-160. KGB Skyrius, Lietuvos Ypatingas Archyvas [KGB Division, Special Archives of Lithuania], Vilnius. (Accessed January 2009).

78. "[Untitled Summary Report]," The Central Committee of the Communist Party of Lithuania. May 1972. LKP Skyrius, Lietuvos Ypatingas Archyvas [Communist Party of Lithuania Division, Special Archives of Lithuania], Vilnius. Fondas 1771, Ap. 247, By. 79. (Accessed 2009). 
that local hippies plotted to steal Kalanta's body, giving this as the reason for changing the time of the funeral on May 18. According to the report,

The Kaunas city division used active measures to obtain information pointing to the intent of the so-called "hippies" to gather together a significant number of their adherents to carry the deceased's casket to the graveyard, and thence to protest by marching across the city to the place of his self-immolation, lay flowers on the site, and hold a demonstration. Certain "hippies" had expressed their intent to seize the body of the suicide victim from his parents by force. ${ }^{79}$

The report noted that the funeral services "were carried out without incident" despite the threat. However, it accused "certain active followers of the "hippie' movement" (specifically Vytautas Kalade and Antanas Kačinskas) of taking advantage of the crowd of young people who gathered at the Kalanta home at the originally scheduled time of the funeral and proposing a march to the city center. The summary report provided a preliminary conclusion that quoted directly from the KGB's determination about the causes of the street demonstrations: "the initial instigators and active participants of the mass anti-social demonstrations were young individuals, who mimicked the "so-called 'hippie' movement." Young people's desire to follow hippies had become a problem, according to the LiCP report, because

until recently, not enough attention has been paid by Soviet, Komsomol, and administrative entities to monitoring the activities of anti-social elements and those who would emulate the 'hippie' movement, weak efforts have been made to conduct preventative propaganda efforts among them, and at the same time no warning was given about the harmful tendencies that have been developing among them..$^{80}$

The May 30 Decree condemned the "harmful influence of the so-called 'hippie' followers, famous for their provocative disheveled appearance, known by their worship of the West, desire for vagrancy and their anarchistic attitude." ${ }^{11}$ Like the attempt to accuse hooligans for the disturbance of public order, the designation of hippies as the culprit was undermined by the demographics of the young people on the streets, most of whom were not actively involved in the small Kaunas hippie movement.

By early June, LiCP officials emphasized not the hippies themselves but young people who were unduly influenced by hippies in order to explain the massive

79. "[Untitled Summary Report]."

80. "[Untitled Summary Report]." Quoting the following KGB document: "Spravka [Memorandum]," Komitet gosudarstvennoi bezopasnosti pri Sovete Ministrov Litovskoi SSR. 1972? Fondas K-1 Ap. 3, By. 793, 142-149. KGB Skyrius, Lietuvos Ypatingas Archyvas [KGB Division, Special Archives of Lithuania], Vilnius. (Accessed January 2009).

81. "Postanovlenie." 
number of young people on the streets. This also marked a change from blaming active agents of unrest to blaming young people who were manipulated rather than expressing their own discontent. The summary report had emphasized that the crowd that gathered at the Kalanta home and carried out the "massive anti-social demonstration" was primarily comprised of young people and concluded by labeling the young people as "politically immature." ${ }^{\prime 2}$ In the May 30 report, Communist authorities noted that the young people themselves did not consider their actions to be anti-Soviet, which demonstrated that they were unaware of what constituted proper behavior. ${ }^{83}$ The June 2 speech by Lengvinas identified the participants in the demonstrations as "young people who did not understand the significance of their actions and who had fallen for the provocations of 'hippies' and similar elements." 84

The Communist leadership turned to the ideological upbringing of youth in order to understand why young people - especially those who were part of the Soviet system as workers, university and secondary school students, and Komsomol members - were susceptible to hippie influence. During the weeks after the May 18-19 demonstrations, the term "unthinking" (or "unaware") was used with increasing frequency to describe the young people on the streets. This designation draws on the Marxist-Leninist meaning of a lack of "consciousness." Unlike "apolitical," this designation emphasized the failure of Soviet organizations to properly inculcate young people with Communist values. Being "apolitical" could be prosecuted as an offense in the Soviet Union because it implied an intentional rejection of Communism. "Political immaturity," on the other hand, implied a lack of agency on the part of young people and instead held others responsible for their failure to act properly.

In the revised narrative of May 18-19, the young people on the streets were not marginalized members of society; rather their "immaturity" led them to hooligan-type actions. By June 2, Communist Party officials had completely moved away from the language of "hooliganism" and instead attributed political immaturity as the defining characteristic of the young people on the street on May 18-19. While the speakers still referred to various "anti-social elements" as a part of the events - hooligans and hippies specifically - their success in disturbing the public order was due to the "political immaturity" of young people who then fell under their influence. In his speech to the Party activists on June 2, Kaunas City Party Secretary Lengvinas stated that the main participants in the "largely spontaneous" disturbances were "young people who did not understand the significance of their actions." Lengvinas described the events as "anti-social demonstrations and the hooliganish actions of a group of politically immature people." ${ }^{85}$ In his speech on June 2, Lithuanian Komsomol Secretary Poškus said "we have encountered cases

82. "[Untitled Summary Report]."

83. "Postanovlenie."

84. "Protokol No. 3."

85. Ibid. 
where young students do not know and do not understand what political vigilance and commitment to principle mean. They connect, judging by what they themselves say on the issue, anti-Soviet activities with mere bad behavior." 86

If the composition of the crowd meant that the authorities could not blame hooligans or hippies as they had initially attempted to do, the decision to identify "politically immature" youth as the cause of the popular unrest was rooted in the discursive possibilities available to Communist Party officials. As the vanguard in the transformation of Soviet society and the only party in the Soviet Union, the Communist Party alone had the responsibility for identifying and eliminating its own flaws. The characterization of the participants as young people whom the educational and Party structures had failed to properly inculcate with Soviet norms and values was consistent with the Soviet practice of "self-criticism." Rather than emphasizing an individual Party member's activity, Soviet self-criticism involved "collective criticism by Party members of the weaknesses of the Party." It involved an often perfunctory claim that the flaws resulted in part from "not having worked hard enough." ${ }^{87} \mathrm{LiCP}$ leaders engaged in the practice of "self-criticism" in their speeches at the June 2 Party activists' meeting. Secretary of the Party organization at the P. Zibertas silk factory, Yakovlev, remarked that the Party "cannot comfort ourselves with the thought that these disturbances arose spontaneously" and called on Party activists to examine carefully who took part in the unrest. In his June 2 speech, Guiga concluded that deficiencies in political work and indoctrination were the primary reason that young people were susceptible to the influence of bourgeois propaganda and violated public order. At the same meeting, Bagdonas asserted that the lack of sufficient indoctrination was "one of the primary reasons why the participants in the street disturbances in Kaunas were primarily young people studying in general education schools or professional technical institutes." 88

The Kaunas Party organization was criticized for a number of failures in the political indoctrination of local young people. The May 30 Decree began by stating that "significant transformations have taken place in the city of Kaunas during the years of Soviet power [...] Nevertheless, the recent unfavorable developments bear witness to the presence of considerable flaws in the work of the Kaunas City Party Organization." The report condemned the city and district Party committees for failing to "pay sufficient attention to developing a deep ideological conviction and political tenacity within young people or the workforce." The report specifically blamed "considerable flaws in the educational indoctrination work in schools and universities, but especially in public and vocational schools." It also criticized the Kaunas Party, Komsomol and various other organizations for failing "to take

86. Ibid.

87. Oleg Kharkhordin, The Collective and the Individual in Russia: A Study of Practices (Berkeley: University of California Press, 1999), 145-146.

88. "Protokol No. 3." 
the necessary measures to expose and interrupt... the harmful influence of the so-called 'hippie' followers." 89

The Lithuanian Communist Youth Organization had particular cause for self-criticism given that one-quarter of the young people arrested were Komsomol members. In his speech on June 2, Komsomol Secretary Poškus admitted that

The basic problem is the fact that Komsomol workers and Komsomol activists have a poor understanding of the popular mood of young people [...] We must openly admit that in certain cases we are doing ourselves more harm than good, fearing to speak openly about individual cases of apolitical attitudes or anti-Soviet hijinks and give them a principled Komsomol evaluation [...] Of course, in this case, blame falls on Komsomol workers and the Komsomol activists.

However, Poškus also attempted to spread responsibility more broadly. He noted that "blame must also fall on the leaders of academic groups and class [school grade] leaders," who lacked the proper ideological knowledge to instruct young people.

Communist Party officials also held parents responsible for the problem of politically immature youth. In his speech on June 14, LiCP First Secretary Sniečkus stated that even the "children of Communists and responsible workers behave in an improper manner, poorly conduct themselves, and dress in a slovenly manner, and yet the parents bear absolutely no Party responsibility." He accused parents of "providing their children with a ruble or two of pocket money, without taking an interest in how the children are spending that money." According to Sniečkus, parents did "not demand that their children return home from school at any particular time. Thus, it is possible to encounter a fairly large number of teenagers on the streets and in parks at 11:00 and even after 12:00 at night." ${ }^{90}$ In a similar vein, Yakovlev denounced young people whose "standard of living is too high, they are allowed too many rights and freedoms." ${ }^{\prime 1}$

In the view of the Communist Party leadership, the young people's actions on May 18-19 represented a failure of proper integration into the collective. ${ }^{92}$ In his June 2 report to Party activists, Kaunas City Party Secretary Lengvinas emphasized the failure of the collective to respond strongly to evident youth problems. He rebuked the leadership of the Communist Party and Komsomol, as well as schools and universities, for being "indecisive in eliminating shortcomings in the education and indoctrination of students" and for frequently failing "to respond to apathy, passivity, poor academic performance, and violations of public

89. "Informatsiia."

90. "Stenogramma sobraniia aktiva Kommunisticheskoi Partii Litvi [Transcripts of meeting of Communist Party of Lithuania activists]," Communist Party of Lithuania. June 14, 1972. LKP Skyrius, Lietuvos Ypatingas Archyvas [Communist Party of Lithuania Division, Special Archives of Lithuania], Vilnius. Fondas 1771 Ap. 247 By. 26. (Accessed 2009).

91. "Protokol No. 3."

92. For a thorough analysis of the role of the collective in Soviet ideology and society, see Kharkhordin, The Collective and the Individual in Russia. 
order." He called for a "serious re-examination of the condition of indoctrination in schools and universities." Lengvinas demanded that those responsible for the political indoctrination of young people actively work "against political apathy, the idealization of the past, and a nihilistic view of the victories of Socialism." $\mathrm{He}$ also connected political immaturity with tolerance for Western cultural practices. According to Lengvinas, "the esthetic and moral indoctrination of students must be fundamentally improved. An unkempt appearance, admiration for the West, and support for 'hippies' cannot be tolerated in our schools and universities." 93 Similarly, Poškus, the head of the LiSSR Komsomol, expressed his opinion that the failure to integrate young people into the collective was the reason for the increase in the number of hippies in Kaunas. He stated that,

it was only the insufficient attention paid to them by Komsomol organizations, as well as other social organizations, that led them to tearing themselves away from their collective, and made it possible for them to unite themselves into separate groups. ${ }^{94}$

LiCP First Secretary Sniečkus clearly situated the events in Kaunas within a broader context of Soviet social and political practices rather than specifically a problem in Soviet Lithuania. He also framed the Party's self-criticism as a renewed commitment to fulfill the mandates of the $24^{\text {th }}$ CPSU Congress, held in March 1971. He reminded party activists that

at the fifth plenary meeting of the Central Committee of the Communist Party of Lithuania, problems connected to the further development of national education in the republic were holistically discussed in light of the 24th Congress of the CPSU. The resolutions that were passed call for concrete measures to be taken to further improve the education and indoctrination of the generation currently reaching adulthood. However, those decrees are not yet everywhere being into practice in the way that they should be.

By referring to Soviet concerns about the indoctrination of youth, Sniečkus diffused possible accusations that the events in Kaunas were unique and that the LiCP itself had, therefore, failed uniquely.

\section{Conclusion}

By defining the demonstrations as a childish outburst, Communist officials denied that the participants might have had legitimate grievances with the Soviet system and denied their capacity to choose to express such grievances. Additionally, "political immaturity" on the part of the participants did not cede cultural power

93. "Protokol No. 3."

94. Ibid. 
to the West. In this narrative, young people were influenced by Western cultural practices not because the West provided a viable alternative to communism, but because the young people were not "politically mature" enough to withstand its corrupting influence. Neither did this interpretation acknowledge real shortcomings on the part of the Soviet Union. The participants' "political immaturity" was caused by a practical failure to inculcate them properly with Communist values, not the failure of the system itself. In the view of Party officials, these young people did not fully appreciate or take responsibility for the benefits of Communist society. As was typical in Soviet political culture, increased Party organization and more Party efforts in providing the proper Communist political education were said to be the remedies. This article makes visible the process by which LiCP officials struggled to articulate an ideologically acceptable narrative about the causes of the demonstrations. Rather than simply repeating Party tropes for public consumption, Lithuanian Communist leaders in 1972 were actively applying and, more importantly, discarding potential interpretations of the street demonstrations as they attempted to articulate an ideologically satisfactory explanation for the events.

At the same time, the analysis of KGB interrogation statements reveals how young people negotiated boundaries by appealing to youthful "curiosity" to explain why they joined the crowds on the streets after Kalanta's funeral. Like "political immaturity," "curiosity" defused the political implications of the young people's participation in the street demonstrations and instead defined it in more childlike terms. In claiming to have acted out of curiosity, the young people denied intentionality in their participation in the street demonstrations. Indeed, by explaining their acts in such a way, young people consciously or unconsciously articulated the same ideological narrative of the street demonstrations as the Communist Party officials. Despite the young people's and Communist Party's insistence that the street demonstrations were not a manifestation of discontent, the analysis of youth cultural practices in Soviet Kaunas demonstrates the extent to which young people were indeed pushing the boundaries of acceptable youth activities.

In his June 2 speech to Party activists about the street demonstrations, Kaunas Party Secretary Lengvinas declared that

youth must realize that the rights that our social order gives them are inseparably coupled with an obligation to carry out their duties, and with responsibility to their collective and to their society.

Like Arūnas in the novel Arberonas - young people in Kaunas were called upon to leave behind the childish life of Western cultural practices and to take their place in Soviet society.

\section{University of California, Irvine}

ajswain@uci.edu 